\author{
ZDZISŁAW GŁĘBOCKI \\ WydZiAE FilOLOGICZNY \\ UNIWERSYTET W BIAŁYMSTOKU \\ EMAIL: GLEBOCKI@UWB.EDU.PL
}

\title{
DIGITAL HOMELAND: POLONIA ON THE WORLD WIDE WEB
}

When my great-grandparents ventured for America at the beginning of the $20^{\text {th }}$ century, one can only imagine the ordeals they went through. Leaving a small Podlasie village (then Russia) in mid-winter, probably illiterate, not knowing a word of English with only the address of a distant uncle in New York City (E. 155 ${ }^{\text {th }}$ Str. 274), they headed for Hamburg, the port of departure, where they boarded the ship "Pisa", and after a long and probably turbulent voyage in class three (sailing the Atlantic in mid-winter is always rough), reached Ellis Island, port of entry to the United States - and reached the Promised Land. There, being made to change their family name from Lewkowicz to Lefkovic (with a diacritic sign over "c"), they moved on further south to the Pennsylvania coal mines of Shenandoah, where they laboured for several years before eventually returning to their native village. In fact, they repeated this cycle twice! "Staying connected" with the family they had left was difficult and in many cases probably impossible. Space and time did matter then. As a result, it meant partly losing their homeland, resulting in deterritorialization ${ }^{1}$.

The present situation of my family, living on what I call a "Polish Island in Western Massachusetts," would have been inconceivable for my great-grandparents - the immigrants of yesteryear. These days, being "fully connected", they enjoy all the benefits of the global communication networks that unite farflung spaces.

Now, diasporic communities of various ethnic backgrounds, of which Polonia is a good example, are able to "connect" with their geographically distant families and homeland and thus simultaneously remain culturally, emotionally,

\footnotetext{
1 The concepts “deterritorialization" and "reterritorialization” were coined by Gilles Deleuze and Félix Guattari in 1972 in Anti-Oedipus (Trans. Robert Hurley, Mark Seem and Helen R. Lane. London and New York: Continuum, 2004). They were later appropriated by anthropologists to refer to the weakening of ties between culture and place.
} 
and intellectually both in their adopted/host cultures and in those they have left behind. This social phenomenon is often referred as reterritorialization.

Among global communication networks, the Internet in particular facilitates the "diasporic public spheres" by creating transnational spaces online. Today, "diasporic websites and forums have become the newest social bases for cultivating national subjectivity and discourse across borders. Immigrants and exiles may be physically displaced from the geographic borders of the nation, but their ability to create independent reading publics provides them with space to analyse critically or express opposition to the policies of their home states" [Parham 2004: 202]. Parham also notes the difference in scope of influence on ethnic communities of traditional media, mainly newspapers and radio, where "their use and impact have generally been restricted to local or regional areas" [Parham, ibidem: 202]. On the other hand, the Internet introduces the potential for creating truly transnational public spheres within dispersed national communities enabling considerably more of its members to be not only recipients, but interactively participate in communication.

As early as 1996, Arjun Appadurai noticed the growing importance of the new medium in the life of immigrant and diasporic communities stating that:

[t]hese new forms of electronically mediated communication are beginning to create virtual neighborhoods, no longer bounded by territory, passports, taxes, elections, and other conventional political diacritics. [Appadurai 1996: 195]

Appadurai was especially interested in the use of media to create "diasporic public spheres" that enable diaspora communities to "imagine" themselves in new ways as part of a linked community even as their members live in geographically dispersed environments. The creation of such mediated public spheres enables participants to "mov[e] from shared imagination to collective action" [Appadurai, ibidem: 8]. These spheres are "... no longer small, marginal, or exceptional. They are part of the cultural dynamic of urban life in most countries and continents" [Appadurai, ibidem: 10]. With its capacity to link many people interactively across great distances, the Internet seems to be the ultimate tool for dispersed ethnic groups wishing to sustain identity in an 'alien' land and work in solidarity with those facing challenges at 'home' [Parham, ibidem: 199].

For diasporic communities like Polonia, globally dispersed across space and time, (and it is interesting to note that the Polish diaspora is fourth in the world with 20 million members; in first place is the Chinese with 30 million, next 
Russian with 27 million, then Italian with 22 million $^{2}$ ), the World Wide Web and electronically mediated forms of communication are ways of manifesting their presence and identity in the global context, providing at the same time an anchor with the homeland. As Clifford [1997: 255] notes, the "language of diaspora is increasingly invoked by displaced peoples who feel (maintain, revive, invent) a connection with a prior home".

This paper investigates the cyber-presence of Polonia on the World Wide Web and first, documents inreach ${ }^{3}$ aspects focused on local communities and the host society and also outreach features geared at "maintaining" links with the homeland and historical contexts. Second, it describes sites which "revive" and "invent" the legendary and "imaginary constructions of nationality, the fantasmatic idea" ${ }^{4}$ of the homeland. This often takes the form of sentimental and nostalgic journeys into the past and geographical locations which are not Poland anymore. Finally, it explores issues connected with marginalized Polonia communities (i.e. the digital underclass) which often lack the economic resources and expertise to participate in contemporary cyberculture.

Several sites turned out to be quite useful as a starting point in the initial research aimed at locating Polonia web pages around the world. Polskiinternet. com, www. polonia.org, the Consulate General of the Republic of Poland in New York site, and the site of Wspólnota Polska - all contain directories of links to worldwide Polonia sites and organizations. Obviously, the directories are not in any way comprehensive and the links data is probably very often coincidental and frequently outdated (some links are obsolete); nevertheless, in spite of these drawbacks, the sites do supply a valuable list, especially for a researcher investigating the global context and not interested in particular national sites.

Polonia web sites are geographically distributed in strict connection both with population trends and economic status. There is a certain perhaps obvious regularity: the larger the Polonia concentration and the higher the income of its members, the more numerous are the web sites. Therefore, North America, especially the United States and Canada, as well as Australia and Europe take the lead, whereas Africa and Asia are least represented. However, there are ex-

2 Data compiled by Michael Pieslak published on Wspólnota Polska site: http://www.wspolnota-polska. org.pl/index.php?id=pwko00, [2.08.2011].

3 The concept of inreach-outreach sites was used by Kyra Landzelius in Native on the Net. Indigenous and Diasporic Peoples in the Virtual Age. Kyra Landzelius (ed.) New York, 2006.

4 Term used by Allen Sekula in an interview in connection with the photographic exhibition Polonia i inne opowieści, at the Zachęta Gallery in Warsaw from the 12th of December to the 28th of February, 2010, Gazeta Wyborcza “Czego nie widać w Kiejkutach”, Kinga Kenig 2009-12-16, http://wyborcza. pl/1,75475,7367931,Czego_nie_widac_w_Kiejkutach.html, [10.08.2011]. 
ceptions to this rule (I will discuss this further in the paper). This regularity is visible in the directory supplied by Wspólnota Polska which seems to be the most comprehensive of the above mentioned sites, and which lists the following number of Polonia web sites in particular countries: Australia - 4, Austria - 6, Belgium - 6, Belarus - 3, Brazil - 1, Canada - 13, Cyprus - 1, Czech Republic - 2, Denmark - 4, Finland - 7, France - 7, Great Britain - 45, Greece - 3, Spain - 4, Holland - 5, Ireland - 12, Island - 1, Italy - 2, Lithuania - 2, Mexico, 1, Germany- 22, Norway - 5, New Zealand - 1, Portugal - 2, Republic of South Africa - 1, Russia - 3, , Switzerland - 3, Sweden - 3, USA - 19. Proportionally, the highest number of sites are those in Ireland (12) and Great Britain (45) which may at first seem surprising. However, related economic and demographic facts might supply an explanation. Recent years have witnessed a large migration of Poles to Ireland and Great Britain. This migration consisted mainly of young people familiar with recent technology, which in effect created a market for Internet based activities.

Polonia web sites may be sorted according to numerous criteria, one of them being generational. Some sites apparently target "old Polonia", whereas others court "new Polonia". The new/old Polonia dichotomy is strictly connected with the waves of migration, where each wave can be characterized by a specific set of social and cultural features. Therefore, on the one hand we have strictly Polish language sites targeting recent immigrants who have close/recent cultural links with the motherland, and on the other hand, English language sites of the second, third, and even fourth and fifth generation immigrants who have lost most of their cultural ties with the motherland and whose Polish identity is reduced to a limited set of features like for example, family name (in fact with often altered spelling) or religion affiliation. Also of interest are what I call the "polkas" and "pierogies" sites. ${ }^{5}$

Let us look at the Polka phenomenon for a moment. As David J. Jackson notes:

The children of the men and women who immigrated to the United States from Poland at the turn of the twentieth century were raised in the United States and generally had no memories of Poland. Their polka music was big band jazz-inspired

Thomas S. Gladsky critically noticed that Polonia "seem[s to be] frozen by stereotypical and reductive portrayals of ethnicity as polkas, pierogies, and pisanki. Too frequently [it] turn[s] to the quaint and charming, the noble and self-sacrificing, the self-indulgent and protective such as our persistent references to the wholesome family and selfless neighborhood, to babcias and ciocias, to wigilia and pisanki, to gentle nuns and inspirational parish priests. Our insecurity reveals itself," but does ,"little to extend or define ethnicity in scholarly terms.” Thomas S. Gladsky, „Beyond Sentiment”, Polish American Studies, Vol. LVIII, No. 1 (Spring 2001), 10, p. 80. 
East coast polka of the 1930s through the 1950s, which was the first music recognized as modern Polish-American polka music...

Big band polka music was the first Polish-American discernibly polka music, and it also was influenced by and in turn influenced the big band jazz of the era. According to Greene, professionally trained musicians of Polish descent generally played it, and it uniquely appealed to Polish Americans born after World War I. From the Depression through the 1950s, it was the dominant form of polka music and it was popular among all Americans, not just the Polish. Big band polka music was played fast, and the arrangements were tricky. More often than not, the lyrics were in Polish, but often they were translations of American popular songs. Sometimes the songs were old Polish folk tunes, but the arrangements and speed with which they were played probably made them at least immediately unrecognizable to Polish Americans who had heard the tunes player and sung with more traditional instrumentation and pacing. [Jackson 2003: 529]

Polka in the United States is promoted by the International Polka Association based in Chicago, which works to preserve the cultural heritage of polka music and to honor its musicians through the Polka Hall of Fame. ${ }^{6}$ Out of numerous polka sites, Bob’s Polka Page (http://www.polkabob.com) lists 33 Polka Sites and dozens of Polka bands located in the United States and Canada.

As to "pierogies", here is a taste of one (http://www.pierogiesplus.com) of the many sites:

Welcome to Pierogies Plus.

Our pierogies are prepared in the Polish tradition by eastern Europeans. If you want more authentic pierogies, you'll have to fly to Warsaw or Krakow. They just don't come any tastier than ours.

If it's been too long since you've had pierogies like Grandma used to make, you've come to the right place - Pierogies Plus. If you can't come visit us, we'll come to you. Don't forget to check out our other tasty menu items and pierogie cooking instructions.

You can also purchase our products on-line, including DVDs that we put together on how to make your own pierogies and stuffed cabbages the old-world way.

Whether you're local to Pittsburgh or across the country, we look forward to providing you with our authentic, made-from-scratch products. Dziekuje!

Join us on FaceBook for special offers, contests and other Pierogie Plus information. And thank you to all of our friends who have joined our online pierogie community! ${ }^{7}$

6 Those not familiar with the polka genre, here is a link to an all-time favourite polka hit "Who stole the Kishka?" http://www.youtube.com/watch?v=EAmLXrMv4-c).

7 http://www.pierogiesplus.com, [8.08.2011]. 
And they do have 1,867 positive entries on Facebook. ${ }^{8}$

The commercial side of Polonia sites should also be noted, where the advertising of commodities and services is common. American Polonia sites are especially beset by ads. The coupon system of product promotion, first introduced in "paper" media, has found its way also onto Web pages: http://www. polishpages.poland.us/? $\mathrm{mod}=$ coupons.

"New" Polonia sites may be exemplified by Polish sites in Ireland. http:// dublin24.net and http://dublinek.net - the Ireland Polish Community Online - both target recent immigrants. Dublin24.net is an all Polish language site, whereas dublinek.net also has an English version. Both sites contain inreach elements focused on local community and outreach material through which they maintain close ties with the homeland. Let us enumerate some of the inreach and outreach items included on these sites ${ }^{9}$.

Inreach:

- a real time online camera located in the center of Dublin

- link to FAS - Northern Ireland's Job Centre - and other job offers

- information about Dublin and Ireland, including geographical and historical data

- step-by-step guidelines and practical tips on how to find a job in Ireland

- information and tips on how to prepare for employment emigration to Ireland - including information on the Personal Public Service Number, Safe Pass and how to establish a bank account in one of the Irish banks

- information about driving licenses

- important addresses and telephone numbers (these include: the Polish Embassy, trade unions, banks, police, bus station, social welfare, etc.)

- a forum with threads such as: family issues, entries according to Irish towns, etc.

- Polish-English on-line dictionary

- Dublin cinema schedules

- Dublin weather report

- articles on local issues, eg.: "Gas bills go up 22 percent", "VAT down!", "Dublin Zombie Walk 2011", "Home and property prices in Ireland are going down", etc.

- Dublin city map, interactive tour of Dublin, events in Dublin

- links to local businesses, eg.: Beauty Salon Dublin, photo.slufirski.com, etc.

An interesting "pierogies" site is also: http://www.pierogifest.net.

9 Both sites [09.08.2011]. 
- classifieds, currencies,

- Polish businesses - find a Polish professional near you

- news - Ireland, United Kingdom, in particular reports on the London riots - 9.08.2011

- interactive "find accommodation", "search jobs", "find an employee", "find business", "buy and sell", "search personals"

- advertisements: credit cards, mortgage, parcels to Poland

In comparison to the inreach material, the outreach items are less numerous and are only limited to:

- links to Polish radio stations

- a link to the Nasza Klasa site.

This may be explained by the fact that the emigrants have arrived in Ireland recently and still have close ties with the motherland both in a physical sense (they have easier possibility of visiting their families due to relative geographical closeness) and in a digital sense (they presumably use the same sites they used before migrating). There is simply no demand to have outreach items included on the sites.

By contrast, far more outreach material is present on North American Polonia sites. For example http://www.polishsite.us - an all English site dedicated wholly to Polish culture, http://www.polskiinternet.com/polski - a Chicagobased site which contains the Polish national anthem, Polish weather report, numerous links to Polish pages and an interesting poster with the slogan "Daj pracę w kraju - kupuj polskie produkty" (Create workplaces in the motherland - buy Polish products).

The "old-new" Polonia generational differences are reflected in political and historical outlooks and result in Polonia's polarization by historical and political allegiances, a phenomenon which has been significantly accelerated by the digital media. Cass R. Sunstein in his influential article "The Polarization of Extremes" published in the Chronicle of Higher Education in 2007, criticized the way Internet users demonstrate their world views (including political opinions) by avoiding information which is not in accordance with their views and preferring content which fully complies with their opinions. He concludes the article with these words:

The Internet makes it easy for people to create separate communities and niches, and in a free society, much can be said on behalf of both. They can make life a lot more fun; they can reduce loneliness and spur creativity. They can even promote democratic self-government, because enclaves are indispensable for incubating new ideas and perspectives that can strengthen public debate. But it is important to understand that countless editions of the Daily Me can also produce serious problems of 
mutual suspicion, unjustified rage, and social fragmentation - and that these problems will result from the reliable logic of social interactions. [Sunstein 2007: B9]

Considering the criteria of political orientation, we can encounter Polonia sites like for example http://www.rodaknet.com, which have strong nationalistic, anti-Jewish, right wing overtones. It is not surprising that the majority of "old Polonia" in the United States and other countries as well, manifests this orientation. It found its expression during the second round of the last presidential elections when Jarosław Kaczyński won a landslide victory in North American Polonia centers. However in countries with a majority of recent "new" Polonia, like for example Sweden or Great Britain, the majority voted for Bronisław Komorowski. ${ }^{10}$ This demonstrates the political differences and polarization between the "old" and "new" Polonia which is more liberal and open to new ideas. As I have stated above - this is a generational issue. Therefore, the "old" Polonia sites adhere to the "Smoleńsk religion" ${ }^{11}$ and now repeat the question: "Who killed Lepper?"

"Old" Polonia sites which "revive" and "invent" the legendary/imagined often fantasmatic homeland are what I call the Kresy ${ }^{12}$ nostalgia sites. Here, the Polish geographical borders are still those of the pre-war. Noteworthy is the logo of the Kresy-Siberia Group site (http://www.kresy-siberia.com/links.html)

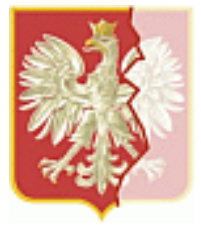

which presents the Polish national emblem in the form of a map of Poland deformed by the missing Kresy section. The Kresy-Siberia Group "is the international special interest group of over 750 survivors of the Soviet persecutions and their 2nd and 3rd-generation descendants. Its objectives are to research, remember and recognize the persecution of Polish citizens of all ethnic and religious backgrounds by the Soviet Union during World War 2." Among its materials are the Virtual Memorial Wall, Research Sources, Books and Films, and Photographs. The Kresy-Siberia Group is also the author of the Kresy Claims site (http://kresy-claims.org/kresyclaims.html) dedicated to winning "[c]om-

\footnotetext{
10 Data on the base of Wirtualna Polska, [10.08.2011].

11 „Herezja smoleńska. Narodziny nowej religii.” Newsweek.pl, 04.05.2011, http://polska.newsweek.pl/ herezja-smolenska--narodziny-nowej-religii,76144,1,1.html, [10.08.2011].

12 In this paper I will use the Polish phrase "Kresy" for the Eastern BorderLands of the II Polish Republic.
} 
pensation for property left outside the present borders of Poland in connection with World War 2". Another interesting site is the interactive Kresy Siberia Virtual Museum (http://kresy-siberia.org) sponsored by an international foundation of the same name.

The general tone of these sites is the military motto "Bóg, Honor, Ojczyzna" (God, Honor, Homeland) first inscribed on the banners of the Polish Army in the West in 1943 and re-introduced in the Polish Army in 1993 - which has since been appropriated by many nationalistic, rightist and skinhead groups. Similar in tone are the World War II veteran sites; for example, http://www. kresy-siberia.com/links.html which is "dedicated to researching, remembering and recognizing the Polish citizens deported, enslaved and killed by the Soviet Union during World War Two."

As has been stated above, the geographical distribution of Polonia sites is strongly connected with economic status. Information inequality leads to social exclusion from participation in cyberspace. It can be concluded that digital participation mirrors, to a great extent, existing economic and class divisions. According to a typology suggested by Aurigi and Graham, "the social architecture of cyberspace" [1998: 63-65] may be broken down into three basic groups: 1 . the "information users": i.e. the digital elite, 2 . the "information used": i.e. digital shoppers, 3. the "off-line": i.e. marginalized groups who lack the financial resources to participate in cyberculture - the digital underclass.

The cyber-presence of the Polonia digital underclass is obviously non-existent on the Web and cannot be traced using digital means. Small Polonia communities scattered across Africa, South America and Asia, especially the former Soviet Republics, are barely represented on the Web. However, there are a few exceptions; for example, Polonia Mozambik (http://poloniamozambik.tripod.com), or http://www.rodacynasyberii.pl, a Polish-Russian language site by the Polonia organization in Abakan, a Republic of Chekasia in southern Siberia which features, among other items, a pdf version of the journal Rodacy documenting the lives of Poles living in Russia.

However, it is not possible to locate any sites of, for example, the ancestors of Polish Napoleonic soldiers still living in the Casale region of Haiti. ${ }^{13}$ This community with a strong Polish identity is excluded from participation in cyberspace due to economic conditioning. It is worth noting that Haiti has arguably the lowest gross domestic product per capita in the world.

As has been documented above, Polonia as a diaspora is widely represented on the World Wide Web. This new medium based on electronically mediated

13 An interesting report on the life of the Haiti Polonia in the Casale region of Haiti is presented in the documentary film by Marian Kutiak Les polonais - Czarna Polonia (2006). 
communication enables its members to interactively participate in the local communities of the host society (the inreach features) and, what is also important, opens up possibilities for creating and maintaining proximity with the homeland in spite of physical distance (the outreach features) [Dufoix 2002: 80]. A truly transnational public sphere, "a digital homeland," within Polonia scattered around the globe has emerged opening new horizons and possibilities for preserving and developing a renewed national identity in the contemporary global context.

\section{Bibliography}

Appadurai A. [1996] Modernity at Large: Cultural Dimensions of Globalization, Minneapolis Aurigi A., Graham S. [1998] "The 'crisis' in the urban realm", in Brian Loader (ed.) Cyberspace Divide: Equality, Agency and Policy in the Information Society, London

Clifford J. [1997] Routes: Travel and Translation in the Late Twentieth Century, Cambridge, Harvard University Press

Dufoix S. [2008] Waldinger R. (Foreword by); Rodamor W. (Translator). Diasporas, Berkeley, University of California Press

Gladsky T. S. [2008] "Beyond Sentiment," Polish American Studies, Vol. LVIII, No. 1 (Spring 2001), Berkeley, University of California Press

Jackson J. D. [2003] "Just Another Day in a New Polonia: Contemporary Polish-American Polka Music", Popular Music and Society, Vol. 26, No. 4, 2003, p. 529-540

Landzelius K. [2006] (ed.) Native on the Net. Indigenous and Diasporic Peoples in the Virtual Age, New York, Routledge

Parham A. A. [2004] "Diaspora, Community and Communication: Internet Use in Transnational Haiti", Global Networks, April 2004, Vol. 4 Issue 2, p. 199-217

Sunstein C. R. [2007] "The Polarization of Extremes", Chronicle of Higher Education, 12/14/2007, Vol. 54 Issue 16, p. B9 


\section{SUMMARY}

\section{Digital Homeland: Polonia on the World Wide Web}

For diasporic communities like Polonia, globally dispersed across space and time, the World Wide Web and electronically mediated forms of communication are ways of manifesting their presence and identity in the global context providing at the same time an anchor with the homeland. This article tracks the cyber-presence of Polonia on the World Wide Web and documents inreach sites focused on local communities and outreach sites geared at establishing links with the homeland and historical contexts. It also explores issues connected with marginalized Polonia communities (i.e. the digital underclass) which lack economic resources to fully participate in contemporary cyberculture.

Keywords:

diaspora, homeland, Polonia, World Wide Web 